\title{
Revolution doesn't die, it simply changes with the times. Interview with Margaret Randall
}

\author{
Gema D. Palazón SáeZ
}

UNIVERSITÉ DE LILLE III · gema.palazon@gmail.com

DOI: $10.7203 /$ KAM.6.7606

ISSN: 2340-1869

KaмCHAтKA. You have a long-term relationship with what the critics would call testimonio in the sixties and seventies. However you have mentioned before how your writing of testimonio did not come about as an academic exercise but as an impulse to know more about other people, especially women. $L a$ mujer cubana ahora (Siglo XXI, 1970) became your first oral-history book. How and why did you start to work on those interviews?

MARGARET RANDALL. I had recently arrived in Cuba from Mexico, where-in 1969-I had begun reading the first feminist documents and articles that were appearing in the United States and Europe. When I got to Cuba, and got a job with a publisher there, my first assignment was to work on a coffee table book about the island's tropical fish and coral reefs. It was a beautiful book, but didn't really interest me. What did interest me was the situation of women in a newly socialist country. I wanted to know if socialism was truly attacking the many problems women have, and if so, how. So I asked my boss 
if I could work instead on a book about Cuban women. The revolution was ten years old, and as yet there were no books on the subject. He was enthusiastic and supportive. That was the beginning of the twoyear project that became La mujer cubana ahora. Apart from the Mexican edition published by Siglo XXI, there were Cuban, Canadian, Dominican and Dutch editions. I really cut my oral historian's teeth, so to speak, on this book; I learned a lot.

KamcHATKA. For your next book, Somos millones or Doris Tïerino: Inside the Nicaraguan Revolution (New Star Books, 1978) you decided to tell the life story of Doris Tijerino. It was the first Sandinista testimonio written by a woman telling a woman's story. You met Doris Tijerino in Cuba, but can you tell us a bit more about how you decided to write her story in the form of a testimonio? Was it personal interest or a political act? What did you want to convey by publishing that particular testimonio in Nicaragua and the United States?

Margaret Randall. You are right, Doris and I met in Cuba, where she and many other Sandinistas were living, training, or recuperating from prison or battle at the time. I knew that the United Nations was going to designate 1975 as the International Year of the Women, and I thought that might be an opportunity to get the story of a woman combatant out to the reading public. I asked Doris if she would be willing to do an in depth (meaning multiple-session) interview with me. As she was a member of a political organization, the Frente Sandinista de Liberación Nacional (FSLN), she naturally had to get authorization from that organization. They were supportive, and we began meeting daily at my apartment. We worked together for almost a year. During that time, Doris discovered that she was pregnant, and also-a few weeks later-that the father of her unborn child was captured and tortured to death in Nicaragua. So it was a difficult time for her. I would interview her each morning, then transcribe our conversation to have it ready for her to read the following morning. In that sense, at least from Doris's point of view, you might say the book was a political act. But the FSLN did not ask to see the final text, nor censor it in any way. For me it was first and foremost an opportunity to tell the life story of an ordinary woman who was born in a particular place at a particular time in history, and ended up doing extraordinary things. Interestingly, I submitted the book to Casa de las Américas' contest that year, but it failed to win.

KAMCHATKA. In Inside the Nicaraguan Revolution you used the first person to tell Tijerino's story. Yo used some of Tijerino's sentences to organize the text but you did not structure it in chapters. Why did you decide to write it that way and how did you determine its structure? 
Margaret Randall. As you note, I had already written Cuban Women Now, which had a fairly conventional structure. I wanted to do something different. I have always believed that form is an essential part of content, and with this new book I wanted to bring form and content together more creatively. So I experimented with a number of different organizational devices. I was still really a novice in this endeavor, so it wasn't easy. I wanted the book to be more like a spiral, inviting the reader to go deeper into Doris's story as she or he continued to read. Ultimately, I ended up grouping Doris' testimony around specific issues. It was the structure the best I was able to develop at the time.

KAMCHATKA. How would you describe your role as an editor of testimonios? Were you ever concerned about whether or not to make yourself visible in these texts?

MARGARET RANDALL. Of course I was concerned with that. I think it is one of the issues that is most problematic to those writing oral history, or even biography if the subject is still alive. How much do we insert ourselves into another's story? Early on, I felt that there should be as little as possible of myself in the women's stories I told. I only included my questions when absolutely necessary. I was really working toward texts in which only the other person's voice would be heard. But I was also conscious of the discussions beginning to emerge at the time about the oral historian's point of view. One of the problems with writing history in the conventional academic manner, was that the historian's point of view, while obviously present, was rarely acknowledged. Thus, a white male upper class historian could write about a poor woman of color from an entirely different culture, and readers were supposed to believe there was no distortion or bias involved. It became important for my generation of oral historians to state up front who we were, where we were coming from, etc. When I became conscious of this issue, I began thinking with each new book about how I wanted to confront it: in an introduction? By including my questions? And I experimented with different ways of doing it. When I was working on a much later book, When I Look Into the Mirror and See You, I at first tried to remove myself entirely from the text. And I got stuck. There came a time when I didn't even think I would be able to finish the book. Eventually I realized that in this particular case, at least, I needed to allow myself to be in the book. It had become a dialogue of ideas, in which both the interviewee's and the interviewer's thoughts were important.

KAMCHAтKA. In the preface of Sandino's Daughters Revisited (Rutgers University Press, 1994) you mention 1971 as the year you started to collaborate/support the FSLN. Could you explain in more detail how you came in contact with the FSLN and how you started collaborating with it?

MARGARET RANDALL. In 1971, living in Cuba, I met several FSLN members who were there for various reasons. My collaboration at that time was in the form of simply helping to get the word out, writing articles for the Left press in the US and elsewhere about what was going on in Nicaragua. As you 
probably know, there was an intentional news blackout on the part of the corporate press with regard to what was happening in Central America and the Caribbean. After the Sandinista victory of 1979, my old friend Ernesto Cardenal was named Minister of Culture in the new government. He was a Catholic priest and poet (still is, he just celebrated his $90^{\text {th }}$ birthday!). Ernesto invited me to Nicaragua to talk to women and write a book about their participation in the recent war of liberation. I did three months of fieldwork, which resulted in Sandino's Daughters (eventually published in Mexico, Canada, the US, Holland, Brazil and a number of other countries). Although I had returned with my fieldwork to Cuba, where I actually wrote the book, the situation in Nicaragua intrigued me. It was a brand new social experiment, with some important differences from the Cuban experiment. I decided to move to Nicaragua at the end of 1980. During my first year I worked at the Ministry of Culture. Then I went to work for the FSLN, helping it to effect the ideological change among the population that was needed to push the project forward.

KaмCHatKa. Inside the Nicaraguan Revolution was first published in Spanish, then quickly translated into English a year later, but it clearly aimed for an international reader if we take into consideration the glossary, vocabulary, historical explanations, maps, and descriptions of Nicaragua and its people. Was the FSLN somehow involved in the preparation of Inside the Nicaraguan Revolution? Did Doris Tijerino ask for permission from the Sandinista Front to tell you her story or did the FSLN have any interest in your work at that time?

Margaret RaNDaLL. The FSLN was in no way involved in the preparation of Sandino's Daughters (or Inside the Nicaraguan Revolution as some of its editions were called. I would never have submitted a manuscript to a political organization for its okay. On the other hand, I am sure, as I have mentioned above, that Doris Tijerino asked permission from her organization to work with me.

KamChatKa. There seems to be some kind of connection between the Sandinista testimonios written in the seventies (...Y las casas quedaron llenas de humo, Carlos, el amanecer ya no es una tentación, and Inside the Nicaraguan Revolution). While other Nicaraguan testimonios from that period focused on descriptions of torture and prison conditions during Somoza's dictatorship, Sandinista testimonios shared a common interest in explaining the revolutionary project and the situation of the country under Somoza's control. Did you share this interest with Doris Tijerino when writing Inside the Nicaraguan Revolution? Did you aim to raise the consciousness of its potential readers? Where you part of any solidarity group at that time?

MARGARET RANDALL. I will answer your last question first. I was not a member of a solidarity group when I did these oral history texts, nor was I later. If I had lived in the United States, I probably would 
have joined one of the groups working at the time in solidarity with Nicaragua or with Central America in general. But I lived in Cuba, where these groups did not exist. So my contribution was based on my sympathy for the Sandinista cause and my personal friendships with people I knew. Later, when I lived in Nicaragua, I simply participated as many other foreigners did. There were hundreds of sympathizers from other countries there at the time, just as there had been many from elsewhere who fought with the Sandinistas during the war against Somoza. As for testimonial texts, there has been a (rather grotesque) tradition of writing about some of these struggles in scandalous terms, emphasizing torture or other lurid details (that tend to sell books). I wanted to tell a more complete story. While I didn't avoid writing about the more dramatic episodes, what I wanted to put across were the superhuman efforts made, and chances taken, by ordinary people-who were giving their lives if necessary to defeat a dictatorial dynasty. And within that overall story, I was interested in telling the story of women's participation. Parts of that story are dramatic, of course, but much of it is simple everyday commitment and sacrifice.

KAmCHATKA. During the eighties, you were involved with the Sandinista Revolution and moved to Nicaragua. Why did you decide to move to Nicaragua and how was that experience? How did you start working for the Ministry of Culture? What were your functions and how long did you work there?

MARGARET RANDALL. I've already alluded to this in my answer to a previous question. I went to live in Nicaragua because, after my three month's of fieldwork there, I found I was extremely interested in the nature of the Sandinista revolution. There was a much higher feminist consciousness there than in Cuba, due no doubt to the fact that the Cuban revolution came to power in 1959 (before feminist thought emerged internationally) and the Sandinistas came to power twenty years later (1979) after feminist texts had "gone viral" as we might say today. The fact that priests and religious sisters took part in the Sandinista revolution also interested me. I myself am not religious or a believer. But I saw liberation theology as a great motivator for change. Vatican II was in full swing then, and its influence on some of the Sandinista leaders was clear (I also wrote a book called Christians in the Sandinista Revolution, an oral history that addressed this issue). The Christian input cast the Nicaraguan revolution in a more humanist mold, as evidenced by the fact that capital punishment was one of the first things the Sandinistas made illegal. As I already said, I had originally come to Nicaragua at the invitation of Ernesto Cardenal, the poet/priest who became the country's first Minister of Culture. When I decided to return to live, he offered me a job at the ministry, which I accepted. I worked there for about a year, in the public relations department. I dealt with invitations to artists from other countries, who were coming to perform in Nicaragua. It was largely administrative work and, although I believed in it, I didn't find it that interesting. So when I had an opportunity to take a more stimulating job, I did. 
KAMCHATKA. "¿Qué es y cómo se hace un testimonio?" was distributed as a manual in the context of the Oral History Workshops of the Ministry of Culture. What was its purpose? How was it conceived and how was it used at that time? Later it was included in the compilation La voz del otro (Beverley, Achugar: 1992) as "Documentos" instead of "Ensayos". How do you read that text today?

MARGARET RANDALL. This was a pamphlet composed of a series of talks I gave, at the request of Nicaragua's Ministry of Culture, during my first visit there at the end of 1979. Cuban Women Now had already come out, and I guess I was considered something of an authority on collecting people's testimonies. The Sandinista revolution was interested in documenting the great changes in people's lives. Everything was happening very fast. People wanted to get the stories down, and the revolution was interested in having this happen. It wanted to be able to keep a fresh memory of the war, people learning to read and write, and so much else. The people collecting these testimonies came from many different educational strata: some were academics with advanced degrees; others had a much lower formal education. So the Ministry asked me to design a workshop that would be helpful to a broad range of "historians." I tried to cover everything from the mechanics of taking testimony (how to work a tape recorder, etc.) to the ethical questions involved. I think it was a useful text for the time and place, but today I don’t consider it to have much importance.

KAMCHATKA. Most of your books include photographs. What role does photography have in your books of testimonio?

MARGARET RANDALL. I apprenticed to a Cuban photographer, Ramón Martínez Grandal (known simply as Grandal) toward the end of 1978. I think I was looking for a non-verbal genre, since I was writing poetry in English and my audience was largely Spanish-speaking. It wasn't long before I became passionately interested in the medium in and of itself. I had been doing oral history for a while by then. I very naturally began photographing my subjects as I interviewed them. I developed an interesting practice of developing and printing my images simultaneous with transcribing and editing my interviews, such that one practice began impacting the other-the images I chose to print, and how I printed them, were influenced by the interviewee's words, and how I edited a text might be influenced by the expressions I saw emerge in the developer tray. It took me a while, but I eventually understood that in my particular creative practice there was an important connection between these two mediums. Later, as I branched out as a photographer, I also began using other of my images in certain of my books. I would prefer not to think of my photographs as illustrating my texts, but rather each genre as an independent expressive form complimenting and enriching the other. 
KAMCHATKA. There have been many debates on what testimonio is and what it is not. In "¿Qué es y cómo se hace un testimonio?" you talked about testimonio as a way to capture history in a moment of urgency (to describe the Sandinista Revolution at the time it was happening), and as a way to democratize history. Do you still think that way? How would you define testimonio 30 years later? How many of your books would you identify under the rubric of testimonio? Would you make a distinction between Inside the Nicaraguan Revolution, Christians in the Nicaraguan Revolution (New Star Books, 1983) and Sandino's Daughters Revisited?

MARGARET RANDALL. I continue to believe that oral history, or testimonio, is important in terms of getting the real story in the voices of those who lived it. Too much history is written by professionals, who may have many useful tools with which they produce their texts, but whose class, race, gender and other conditions prevent them from truly understanding the lives of those about whom they write. On the other hand, many academic historians have adopted oral history practices in recent years, and incorporated them successfully into their work. And many oral historians have begun to understand the value in accurate documentation and other more academic practices. So there has been a certain amount of overlap between what is considered written and oral history. In my particular case, as a poet and artist, I have always played around with genres, trying to break down the rigid divisions and moving in whatever direction I feel will enrich my text. I have no idea how many of my books I would call oral histories, since some are simply that and others contain elements of other genres. The main difference between each of my titles and those that precede it, is that each new book improves upon those that came before. Or at least I hope it does. I am constantly looking for new ways to say what I want to say. In Sandino's Daughters Revisited I go much farther than I was able to go in Sandino's Daughters, both because the women themselves, once Sandinismo had been defeated, felt more free to tell more of their stories... and because I had more fully grown into some of the ideas I was developing through years of experience and analysis.

KAMCHATKA. You have been very committed to women's lives and feminism. At the same time you collaborated with two revolutionary movements (in Cuba and Nicaragua), which were also criticized for their actions regarding gender politics. In regard to Sandino's Daughters (New Star Books, 1981) and Sandino's Daughters Revisited, how did you navigate those two projects?

MarGaret Randall. From the moment I became aware of feminism, it changed my life. I am committed to feminism as an ideology because I believe it gives us the tools to understand power. And I see power-its use and abuse-as central to every struggle. I worked in two revolutionary movements, as you say, that have been highly criticized for their gender politics. But they were at the vanguard, at the 
time, of the effort to change society. Gender is not the only consideration in regard to social change. Class, race, culture, and many other variables are important as well. Like many of the other women involved in those two movements (and in other movements), I grew with experience.

KAMCHATKA. Even though both books concern women's situation and its evolution in Nicaragua, Sandino's daughters revisited only re-interviewed two of the women in Sandino's daughters. How did you manage the selection process and why did you decide not to interview/publish all the women included in Sandino's Daughters?

MARGaRet RANDALL. My original intention was to go back to each of the women I'd interviewed for Sandino's Daughters, and interview them again, with an eye to how their stories may had changed 12 years later. But this proved impossible. Several of the women were no longer alive. I couldn't locate a few others. And of course I met other women whose stories I wanted to tell. My main objective was the collective story. And I found that I could tell that story best by interviewing the women I interviewed for the second book. I also confronted the new book's introduction differently, going much farther out on a limb in order to analyze what I saw as women's role in social change-especially the systemic challenges involved.

KAMCHATKA. You have described When I Look Into the Mirror and See You: Women, Terror and Resistance (Rutgers University Press, 2002) as the book where you found a circular structure to tell these kind of stories. How would you describe this approach and why do you consider it more suitable compared to the interview or narration in first person?

MARGARET RANDALL. Like all works of art, I believe the work itself must tell the story. I don't want to describe When I Look Into the Mirror and See You, but rather let the book tell its own story in its own way. But I will say that I sought a circular way of storytelling because I do not really believe in linear history. I am much more interested in the ways we may go around and around as we go deeper into a given story.

KAMCHATKA. Do you think literature might have a role in the present struggles for social change, as it seemed to have in the Cuban and Nicaraguan revolutions?

MARGARET RANDALL. Long before the Cuban and Nicaraguan revolutions, literature had a role in social change, and long after. Literature has always been a vital part of social struggle and change. Serious literature is generally not written to effect social change; it simply does so because it reflects events, protagonists, cultures, issues, dangers, and possible solutions. 
Revolution doesn't die... Interview with Margaret Randall

KAMCHATKA. Many literary critics and academia consider testimonio in past tense, as if its possibilities were gone after the failure of the revolutionary movements. Do you agree with that?

Margaret Randall. No I don't. The academy and the corporate media are often quick to say something is dead, because they trade in particular moments and fail to understand ongoing evolution. Look at how many pundits have said that feminism is dead! And look at the way in which the US corporate press insists on so-called impartiality even as it allows its journalists to be embedded with its military units in Afghanistan and Iraq. Journalistic impartiality is a myth, though few understand that this is so. The Sandinista revolution is no longer in power (despite Daniel Ortega's obscene affirmations), and the Cuban revolution has gone through enormous changes. But the latter is still alive, and bits and pieces of the former as well. And there are new revolutionary experiences throughout Latin America (Uruguay, El Salvador, Bolivia, etc.) and in the rest of the world. Revolution doesn't die, it simply changes with the times. Until there is justice for people everywhere, there will continue to be movements for social change. In this same way, there will always be a need for people to be able to tell their stories, and for the public to hear them.

KAMCHATKA. In January 2011 you were invited by Casa de las Américas to be a judge in the category of testimonio. How was that experience? Do you feel the category of testimonio as genre has changed through the years?

MARGARET RANDALL. It was a very rewarding experience, as all experiences in Cuba have been for me. I was first invited to be part of Casa de las América's literary jury in 1970, when I judged books in the poetry category. Jorge Fornet, who runs the yearly contest these days, joked and said they were going to invite me every 41 years. As you say, in 2011 I judged the testimonio category. And this was particularly moving for me because 41 years earlier Rodolfo Walsh from Argentina had suggested they add that genre to the several in which they give prizes. Rodolfo was a good friend, murdered by the paramilitary forces in his country several years later. His own book, Operación masacre, was an important forerunner of Latin American testimonio.

Testimonio has changed over time, as I think all literary genres tend to do. As a genre ages, hopefully it also becomes richer, incorporating the ideas and experiences that have defined it up to that point. I think that testimonio, as a product of social upheaval, has perhaps been most interesting in historic periods in which social change has been most dramatic. But, as I've said before, although they may not be as dramatic as the Cuban or Nicaraguan revolutions, there are a number of instances of social change taking place right now. The book to which we awarded first prize in 2011 was written by an Argentinean; it was about a prison experience, and I thought it was excellent. Testimonio, as a literary 
Revolution doesn't die... Interview with Margaret Randall

genre, continues to have tremendous potential for innovation and empowerment. It can also get bogged down in traditions that, as in other literary genres as well, can be sure recipes for disaster.

KAMCHATKA. Some of the debates on testimonio in Latin America in recent years have focused on the challenges of making memory -and subjectivity- central to History and have problematized the use of testimonio as the main narrative of history. What do you think about the relationship between testimonio, history, and memory?

MARGARET RANDALL. I think that some of these debates are important, others superfluous. Individual as well as collective memory are both tremendously important to me. In fact, they are central to my work. One of the things that have been done to women in particular is that we have been robbed of our memories, silenced into submission. And whose memory should we trust more than the person who has lived the experience? Of course memory can be subjective. But memory filtered through a second or third party is also extremely suspect. Our culture tends to dismiss subjectivity, as if it is an evil. In journalism, for example, we cultivate the largely specious illusion we call objectivity or impartiality. We are taught to trust the impartial observer, as if there actually is such a person. I have never said that testimonio or oral history should be the main narrative of history, only that the protagonists' experience and point of view be included in what we call history.

KAMCHATKA. After the Sandinista defeat in 1990 many other testimonios were published following the same structure that was institutionalized during the eighties but against the Sandinista discourse of the Revolution (testimonios by the Contras, memoirs by people who served during the Obligatory Military Service, recognized Nicaraguan writers, etc). Have you read any of these books? If so, do you feel any connection to the testimonios published during the eighties?

MARGARET RANDALL. All worthwhile literature is connected. I have read some of these books, and find many of them interesting. I remember two books in particular, written by Chilean women who were members of Left organizations and turned against their comrades during torture. Both "saved themselves" by working for the enemy, and eventually ended up writing about the experience. I found both of these books extremely interesting. One goes to different books for different reasons. I do not only read books written by those with whom I know I will agree.

KAMCHATKA. Somehow, memory has been central to your literary production (poetry and narrative). You have worked with memory from political, collective, and personal perspectives. Are you still interested in memory from these three perspectives? 
Revolution doesn't die... Interview with Margaret Randall

MARGARET RANDALL. I am interested in memory from every perspective, including cellular memory (memory one may not retain in the conventional sense but that lives in one's cells).

KAMCHATKA. Finally, we would like to know a little bit more of your current literary projects and interests. We would also like to thank you for your time and generosity in answering our questions.

MARGARET RANDALL. Good questions are always thought provoking, and always teach me a great deal. So I, too, am grateful for this interview.

Currently, I have several ongoing projects. I am always writing poetry, and have begun to put together my next collection, She Becomes Time. Wings Press, in San Antonio, Texas will bring it out next year. I am particularly grateful to Bryce Milligan at Wings for his attention to my poetry and for the beautiful books he has designed and published for me over the past decade. I also spend quite a bit of time writing features and opinion pieces for an on-line publication called New Mexico Mercury. I do at least one long piece and often one or two shorter ones for them each week.

This past year I have also worked hard on a book about the Cuban heroine Haydée Santamaría. Haydée was one of only two women who, along with 160 men, attacked Moncada Barracks in Santiago de Cuba on July 26, 1953. This action was a military failure but politically it was the event that sparked the Cuban revolution. Haydée went on to participate in every phase of the struggle, and following victory in 1959 she was charged with founding and running Casa de las Américas, which would become one of the most important cultural institutions in the Americas. This woman, who grew up on a sugarcane plantation and barely had an elementary school education, was a genius at bringing the world's great artists to Cuba and promoting the work of Cuban artists and writers. Almost single-handedly, she broke through the US cultural blockade. She promoted Cuban artists who suffered from the narrowmindedness the revolution occasionally showed. And she developed a way of working at Casa that was truly horizontal and democratic. Casa continues to work in this way because of her legacy.

I knew Haydée when I lived in Cuba; she was a friend and a mentor. She committed suicide in 1980, and as a result has never really had the attention she deserves. I had long wanted to write about her. I had done so in poems and shorter prose pieces, but had never had the courage to devote a whole book to her life. A couple of years ago, I realized it was either "now or never." I was able to interest my editor at Duke University Press in the project, and in April of last year I traveled to Cuba to do the fieldwork for the book. I spent the rest of the year writing, and have recently read final page proofs. Haydée Santamaría, Cuban Revolutionary: She Led By Transgression will be coming out in September 2015. 